\title{
10 'Monstrous and Indefensible'? Newspaper Accounts of Sexual Assaults on Children in Nineteenth-Century England and Wales
}

\author{
Daniel F. R. Grey
}

\section{Introduction}

On 30 November 1899, the British periodical Truth ran a scathing article following the conviction of two teenage boys at the Devon Assizes for the indecent assault of a 6-year-old girl. The paper's ire was not, however, directed at the felons. Instead, Truth lambasted Mr Justice Day for what the journal considered an outrageously harsh sentence, arguing that 'however depraved' the guilty parties might be, to sentence the younger of the two convicts to nine months' hard labour was 'a monstrous and indefensible punishment' given that he was only 13 years old. ${ }^{1}$ For the historian who has been able to read the archival Home Office file relating to this case, which (unlike the terse newspaper accounts of the trial) graphically described the gruesome and distressing details of the attack on the victim, this explicit sympathy for the boys in the dock seems doubly shocking. That the periodical was emphatically more outraged by what the anonymous journalist perceived as an overly reactionary sentence by a heavy-handed judge than by the crime itself, a reaction which seems to have been shared by at least some of the spectators in the public gallery, ${ }^{2}$ speaks to the complexities (and indeed the limitations) of the discourses that surrounded cases of sexual violence against children during this period. ${ }^{3}$ If children who had been sexually abused might sometimes

1 Truth, 30 November 1899. It is worth noting that the report of this same trial in local newspapers was a mere ten lines each and gave minimal details - nor did it protest the sentence. See Trewman's Exeter Flying Post or Plymouth and Cornish Advertiser, 25 November 1899, 5; Western Times, 29 November 1899, 2.

2 The chief constable of Devon informed the Home Office in a letter on 12 January 1900 that Mr Justice Day having sentenced the older teenager to six years penal servitude 'caused somewhat of a sensation in the Court when pronounced'. The Home Office decided that it would be best to treat each young man as in practice serving sentences of 3 years and four months, respectively. See The National Archives, HO 144/467/V30001.

3 See the groundbreaking study by Jackson, Child Sexual Abuse, and also especially Bates, Sexual Forensics. 
manage to avoid some of the difficulties and overt hostility faced by adult women who attempted to seek redress through the Victorian criminal justice system, the similarities in prosecution and punishment (or lack thereof) between trials for sex offences that were committed against adults and those against children were much more pronounced than their differences. ${ }^{4}$ Neither sympathy nor justice was ever guaranteed for child victims in either the press or courtroom. ${ }^{5}$ As I demonstrate here, representations of individual acts as 'monstrous and indefensible' were not necessarily confined to sensationalised descriptions of the defendant, but might also serve as a useful shorthand for the ways that in practice both the authorities and the media often approached the subject of child sexual abuse during the nineteenth century.

Although it has long been acknowledged that the growth of the press played a significant role in nineteenth-century culture and society, it is only recently that historians have begun to critically examine the influence of crime news as an important genre of reporting in its own right, one that profoundly shaped public understanding of law, crime, and punishment. ${ }^{6}$ While rich and nuanced book-length studies of child sexual abuse in nineteenth-century England by Louise Jackson and Victoria Bates have transformed our understanding of the ways this subject was identified, understood, and dealt with by the criminal justice system, media representations of these cases have not been their primary concern. ${ }^{7}$ Identifying relevant cases through keyword searches in digitised newspaper databases, such as the British Nerwspaper Archive, Telegraph Historical Archive, Times Digital Archive and Welsh Nerwspapers Online, this essay examines the reporting of sexual violence against children in England and Wales between 1830 and 1914 and explores what these articles - not least of which the euphemisms and elisions they frequently resorted to - reveal about attitudes to gender, childhood, and crime in this period. ${ }^{8}$

${ }^{4}$ On cases involving adult women victims, see Conley, 'Rape and Justice in Victorian England', 519-36; D'Cruze, Crimes of Outrage; Stevenson, 'Unequivocal Victims', 346-66; Bourke, Rape; Barrow, 'Rape on the Railway', 41-56.

5 For the specific challenges facing child victims in giving courtroom testimony, see especially Jackson, 'The Child's Word in Court'; and Stevenson, "'Children of a Very Tender Age Have Vicious Propensities"'.

${ }^{6}$ King, 'Newspaper Reporting', 73-112; Crone, Violent Victorians; Rowbotham, Stevenson and Pegg, Crime News in Modern Britain; Barrie, 'Trial by Media', 349-76. An important comparison with this issue in the American context is provided by Freedman, "Crimes which Startle and Horrify", 465-97.

7 Jackson, Child Sexual Abuse, and Bates, Sexual Forensics.

8 Because of Scotland's separate legal system, I focus here on reports from England and Wales. On child sexual abuse in Scotland, see Dunning, 'Narrow Nowhere Universes', 113-25. 
In particular, I focus here on two main themes: the media representation of the victims and that of the perpetrators. ${ }^{9}$ Cultural constructions of gender, age and class (including the nebulous but important concept of 'respectability', which never mapped straightforwardly onto other categories) were essential elements in all such representations not only for the prisoner on trial, but also in shaping responses by both juries and journalists to the victim and her or his testimony. ${ }^{10}$ Historians have noted that the use of such electronic newspaper databases is hardly unproblematic, given the potential for these resources to skew the findings in terms of either what keyword searches might reveal or leading to possible overdependence on particular individual newspaper titles such as The Times, the middle-class 'newspaper of record'. For example, it is absolutely impossible to estimate how many articles were published relating to English or Welsh cases of suspected child sexual abuse during the long nineteenth century. Even key phrases such as 'outrage', which could often be used as a Victorian code word for sexual violence, cannot be reliably assumed to refer to this subject, and similarly ambiguous expressions were of course also used in multiple alternative contexts, some of which had nothing at all to do with crime or violence. ${ }^{11}$ Locating reports of child sexual abuse in the nineteenth-century press (especially those that consist of more than a curt sentence or two, even when the defendant was found guilty) thus remains a difficult and time-consuming exercise. ${ }^{12}$ Nonetheless, these new digital resources undoubtedly allow for a much wider potential dataset to be collected than would otherwise be the case. ${ }^{13}$

9 It would normally be automatic for scholars to anonymise such cases, but the information in newspaper articles (along with published law reports or similar documents) is already in the public domain, since the British press continued to publish the names of both defendants and victims well into the twentieth century. Certain cases, especially those involving the most heinous examples of violence or allegations against public figures, are also often sufficiently well-known that anonymity is redundant. This poses particular and complicated ethical challenges for historians: see invaluable discussion of these issues in Bingham, Delap, Jackson and Settle, 'Historical Child Sexual Abuse', 423-26. Indeed, in the case of Open Access digital resources drawn on for this essay such as the Old Bailey Proceedings Online (www.oldbaileyonline.org) or Welsh Newspapers Online (http://newspapers.library.wales/), these reports are freely available to all. For these reasons, I have not anonymised the nineteenth-century cases cited here.

10 Stevenson, 'The Respectability Imperative', 237-48.

11 Stevenson, “"Crimes of Moral Outrage", 232-46.

12 For example, the report that an engineer named James Hunter at South Shields Police Court had been sentenced to four months imprisonment for the indecent assault of a four-year-old girl comprised literally one sentence. See Shields Daily Gazette, 16 December 1872, 4.

13 For the benefits and limitations of searching digitised historical newspaper databases, see discussion in Upchurch, 'Full-Text Databases and Historical Research', 89-105; Nicholson, 'The Digital Turn', 59-73; Hobbs, 'The Deleterious Dominance of The Times', 472-97; Fried, 'No Irish Need Deny', 829-54. 


\section{Newspapers as a Source for Understanding Child Sexual Abuse in Victorian England and Wales}

From the late 1790 s onwards, British newspapers and periodicals and sometimes even law reports, perhaps most significantly including the influential and semi-official Old Bailey Proceedings $(O B P)$ - were increasingly liable to skim over the reporting of sexual offences in particular as being 'unfit for publication'. ${ }^{14}$ This stands in marked contrast to reportage of crimes such as infanticide, which were only very rarely marked as 'unfit' and could often produce very detailed articles right up until the outbreak of the First World War..$^{15}$ For example, while the $O B P$ could and did often go into a great deal of detail about testimony heard at individual criminal trials, the case of William Kinsey, charged at the Old Bailey in June 1836 for the rape of 9-year-old Martha Griffin at Tottenham, merely recorded the age of the victim, the location and date of the crime, and the verdict: 'GUILTY - DEATH' ${ }^{16}$ Even those criminal cases that provoked a national outcry and received voluminous press coverage, such as the infamous murder and dismemberment of 8-year-old Fanny Adams by Frederick Baker in 1867, the possibility of sexual violence was only alluded to rather than acknowledged with the detail given to other gruesome aspects of the case. ${ }^{17}$ Both Judith Flanders and Samantha Pegg have reflected specifically on the murder of Adams as a case where the press tiptoed around reporting this as a potential or actual sexually motivated killing, despite the widespread assumption that this was what had led to the crime (and Baker's specific denials he had molested Adams), and being willing to provide graphic details of the crime in other respects, including clear allusions to cannibalism. ${ }^{18}$

Journalistic aversion to discussing sex crimes remained strong throughout the nineteenth century even in articles where this was

14 On cases of child sexual abuse as reported in the $O B P$ before 1800 , see Gammon, "'A Denial of Innocence"', 74-95; Walker, 'Rape, Acquittal and Culpability', 115-42; Toulalan, 'Child Sexual Abuse', 23-44; Gollapudi, 'The Disordered Fundament', $45-56$.

15 Grey, “"Agonised Weeping”', 468-80.

16 Old Bailey Proceedings Online (oldbaileyonline.org version 7.2, 31 March 2016), June 1836, trial of William Kinsey (t18360613-1385).

17 This case, along with Baker's trial at the Winchester Assizes and his subsequent execution, were reported widely - for reasons of space, few examples can be provided here, but see the extensive reports of the trial in Hampshire Chronicle, 7 December 1867, 9; The Times, 7 December 1867, 12.

18 Flanders, The Invention of Murder, 381-4, 430; Pegg, 'Sweet Fanny Adams and Sarah's Law', 83-4. 
integral to the report, such as the so-called 'Maiden Tribute' scandal of 1885. In this case, a series of sensational articles in the Pall Mall Gazette by the crusading journalist W.T. Stead about prostitution and human trafficking lead to a public outcry at the incidence of child sexual exploitation. ${ }^{19}$ The scandal that erupted from this exposé was in large part responsible for both the repeal in England and Ireland of the Contagious Diseases Acts, which targeted suspected sex workers, and for the passage of the 1885 Criminal Law Amendment Act that, among other matters, raised the age of consent for sexual intercourse from thirteen to sixteen. ${ }^{20}$ This tendency by the press to omit or skim over the details of sexual offences does not mean that such reportage was entirely erased from the print landscape during the nineteenth century. ${ }^{21}$ Instead, as Kim Stevenson has noted, '[T]o maintain a respectable discourse certain linguistic codes and euphemisms were invoked to disguise sexually explicit material and descriptions including doubleentendres, contradictions and metaphors'. ${ }^{22}$

Given these issues, the question might be asked why then focus on newspapers at all as a source, since this invariably means that historians trying to research sexual offences in England and Wales during this period are forced to try and build up broader mosaics from often piecemeal reports? The answer to this lies in the serious problems with gaps in the surviving archival record, whereby only around 2 per cent of English depositions (the pre-trial witness statements made before a magistrate or coroner) from assize trials have been preserved in the National Archives at Kew. ${ }^{23}$ Court records of sexual offences tried at the assizes in England and Wales seem to be particularly sparse within this surviving sample, the majority of which specifically deal with murder trials. ${ }^{24}$ While records of sexual violence might, in rare instances,

19 Pall Mall Gazette, 6 July 1885; Pall Mall Gazette, 8 July 1885; Pall Mall Gazette, 10 July 1885.

20 Soderlund, Sex Trafficking, 24-66.

${ }^{21}$ Barrow, 'Rape on the Railway'.

22 Stevenson, 'Outrageous Violations', 45.

23 Depositions from Wales generated after 1830, when the North Wales and South Wales assize circuits were created following abolition of the Court of Great Sessions, are also held at Kew, in roughly similar rates of preservation to the English ones. For the context of Welsh criminal justice after 1830, see Watkin, The Legal History of Wales, 168-96.

${ }^{24}$ For this reason, both Louise Jackson and Victoria Bates drew on depositions from relevant Quarter Sessions cases that have survived at county record offices, as well as using assize trial records held at the National Archives. Quarter Sessions, heard before magistrates, dealt with serious misdemeanours rather than felonies, and as with assize trials, these records survive in variable quantities. See Jackson, Child Sexual Abuse, and Bates, Sexual Forensics. 
be generated through other artefacts, such as the autobiographical sampler stitched by 17-year-old Elizabeth Parker in 1830, these objects are exceedingly rare. ${ }^{25}$ Newspapers are thus often in practice the best way to find information regarding criminal cases from this period. ${ }^{26}$ There are also additional challenges that must be overcome in accessing what relevant archival material has survived because of concerns about data protection, and the possibility of causing distress to the descendants of those involved. Despite their limitations, newspapers thus remain an essential tool for understanding the history of sexual violence and, indeed, of sexuality and law, more broadly, in nineteenth-century England and Wales. ${ }^{27}$

\section{Representing Victims of Child Sexual Abuse}

Because of the coded language or outright silences in many reports relating to sexual offences, it can sometimes be difficult to pinpoint from newspaper articles the motivations behind some offences that potentially crossed lines between seemingly unrelated crime and sexually motivated attacks. Was, for example, the case of a 9-year-old boy on his way home from school in Kent who, as the Cardiff Times reported in January 1889, met a man and 'who stripped him naked and left him in the cold without a vestige of clothing on'28 simply a case of opportunistic theft, or was this a coded reference to a sex attack? In fact, this case turned out to actually involve neither crime: the boy admitted six days later that this had been an elaborate (if ill-judged) fabrication to avoid getting into trouble with his parents after playing truant from school - the fact that it had ended up reported in the national media ultimately forcing him to confess. ${ }^{29} \mathrm{In}$ other instances, however, thinly concealed references to the sexual abuse of children are much more immediately identifiable. In September 1908, for example, 29-year-old William Henry Manser, a printer, was charged

25 Flower, 'Wilful Design'.

${ }^{26}$ A study of infanticide cases prosecuted on two of the three English assize circuits with a full run of surviving criminal justice papers between 1880 and 1922 found that pre-trial witness statements had been preserved for just 17 per cent of the 646 defendants indicted. This is particularly startling given infanticide depositions are perhaps the most likely to have been preserved as 'of interest' by the clerks of assizes, and thus make up a disproportionately high number of such records. See Grey, 'Discourses of Infanticide', 8.

27 Stevenson, 'Unearthing the Realities of Rape', 405-23; Upchurch, Before Wilde, $102-3$.

28 Cardiff Times, 12 January 1889, 2.

29 South Wales Echo, 18 Jan 1889, 2. 
at the West London Police Court with having unlawfully enticed away a 9-year-old girl with intent to deprive her parents of custody. The magistrates heard that the initial charge of kidnapping, which he was there to answer, had recently been followed with another charge of indecent assault against the girl in question, since the police divisional surgeon reported although 'the child when first examined bore no marks of violence, but had since developed certain symptoms'. ${ }^{30}$ This was a thinly veiled but important reference to the fact the girl was now apparently suffering from venereal disease, most likely gonorrhoea, the diagnosis of which could sometimes (but by no means conclusively) increase the chances of successfully prosecuting child molesters in both Britain and America. ${ }^{31}$ This was in part because of the importance of corroborating evidence that could supplement the testimony of the victim, since without this, even what newspapers considered 'a very plausible story' and the opinion of a doctor that the child had been molested might still lead to a prosecution being abandoned. ${ }^{32}$ Conversely, in those cases where 'the medical evidence showed that the child had received terrible injuries' during their attack, securing a conviction became much more likely. ${ }^{33}$

Although most identifiable victims in nineteenth-century newspaper reports were girls, cases involving sexual assault on boys were also reported by the press, even if, as Louise Jackson has pointed out, this could involve journalists resorting to even more euphemism, silences and evasions than those that were utilised in articles about similar crimes with female victims. ${ }^{34}$ Partly, this was because attacks carried out by men or youths on boys, unless tried under the rubric of indecent assault, were likely to be prosecuted as sodomy cases (or, after 1885, under the catch-all of 'gross indecency'), using precisely the same legislation that also targeted grown men having consensual sex with other adult males. ${ }^{35}$ There were also serious questions amongst some late-Victorian medical jurists that were analogous to the pervasive rape myths that proved so damaging in trials for sexual violence against women and girls. ${ }^{36}$ These focused on the question of whether it was even physically possible for men to rape other males, regardless of the

30 Daily Telegraph, 3 September 1908, 5.

31 Bates, "So Far as I Can Define without a Microscopical Examination", 38-55; Sacco, Unspeakable.

32 Herald of Wales and Monmouthshire Recorder, 21 August 1897, 6.

33 The Cardiff Times, 26 May 1904, 7.

34 Jackson, Child Sexual Abuse, 99, 102, 104.

35 Cocks, Nameless Offences; Upchurch, Before Wilde.

36 Bourke, Rape, 21-49. 
victim's age or other factors. ${ }^{37}$ While overt public discussion of this idea was seemingly a step too far for the press, even in those articles willing to do more than refer tersely to a trial for 'unnatural offences', these ideas undoubtedly influenced attitudes within the courtroom. As was the case in trials for the sexual abuse of girls, conviction rates began to decline sharply if the age of the boy attacked was over 12 years old, and (just like women and girls) working-class male victims were liable to be cross-examined fiercely on the assumption that almost all reports of sexual violence were falsified by scheming and malicious accusers. ${ }^{38}$ Unlike in cases with female victims, however, boys were liable to be stereotyped during cross-examination as thieves, delinquents and extortionists rather than as sexually precocious. ${ }^{39}$ Instances in which adolescent boys were believed by the courts to have had any sort of sexual contact with other males prior to their assault seem to have been very rare, but if this was suspected, the case was promptly dismissed. ${ }^{40}$ In the early and mid-nineteenth century, a climate of judicial paranoia about potential blackmailers falsely accusing wealthy men of having made sexual advances to men or boys could even mean that those male victims who reported such an attack could end up on trial themselves. When John Webber was acquitted for the indecent assault of a 13-yearold boy in 1842, he promptly brought a counter-prosecution against the boy's father, the child in question, and other relatives. ${ }^{41}$

The heavy emphasis in medical jurisprudence - and often in the press on the supposed unreliability of witness testimony and potential dangers to 'innocent men' from the mischievous or malevolent did not mean that there was a blanket denial of the existence of child sexual abuse, however. ${ }^{42}$ What does seem to have been clear, in a direct parallel with contemporary reportage of sex crime, ${ }^{43}$ is the overwhelming preference for newspapers to provide greater detail or, at the very least, seemingly clear-cut narratives in cases of rape and molestation by strangers or slight acquaintances than similar crimes that were committed within

37 Dixon Man, Forensic Medicine E Toxicology, 117; Luff, Text-Book of Forensic Medicine and Toxicology, 273. This issue is explored further in the American context by Robertson, "Boys, of Course, Cannot Be Raped"', 389-416.

38 Bates, Sexual Forensics, 88; Jackson, Child Sexual Abuse, 103.

39 Bates, 'The Child as Risk'; Jackson, 'The Child's Word in Court', 230-4.

40 Bates, Sexual Forensics, 88.

41 Upchurch, Before Wilde, 33-5.

42 See, for example, the discussion of how to determine 'true' from 'false' signs of sexual violence on the bodies of alleged victims in Taylor, The Principles and Practice of Medical furisprudence, 989-92.

43 Greer, Crime and the Media. 
communities or, even worse, within families. This cultural aversion was, in part, why incest did not become a criminal offence in its own right in England and Wales until 1908, and prosecutions under the new Act after this time were held in camera, strictly forbidden from being reported on by the press. ${ }^{44}$ Thus, victims arguably stood the greatest chance of a sympathetic story, with the newspaper focusing on the villainy of the attacker, if the accused was a stranger. ${ }^{45}$ In reporting the rape of a 13-year-old girl at New Quay in southwest Wales in November 1878, the Western Mail headlined this as 'The Tramp Nuisance' and focused explicitly on the idea of 'stranger danger', noting that the arrested man had '.. been known about the district for the last ten or twelve years, and is a ruffianly-looking fellow, of about 31 years of age'. ${ }^{46}$

However, sympathetic press reportage regarding victims of child sexual abuse was also highly dependent on the girl in question conforming to preconceived notions of respectable femininity and, even more significantly, 'innocence'. ${ }^{47}$ Even in cases where the guilt of the defendant was clearly established and a heavy sentence bestowed upon the prisoner, such as the 1870 conviction of a 40 -year-old labourer for the rape of his 8-year-old niece in rural Suffolk, when handing down a sentence of 15 years' imprisonment, the judge spent more time ruminating on the fact that the victim had been left, as he saw it, irreparably tarnished in both body and mind - 'ruined ... for the remainder of her life' - than in condemning the prisoner. ${ }^{48}$ The idea of sexual innocence, in particular, was heavily loaded, since young people even knowing correct anatomical names or basic facts about reproduction might be viewed with dire suspicion: Hera Cook has noted that parents at one school in Derbyshire in 1914 were so horrified by the headmistress providing sex education classes to children that they sought her dismissal. ${ }^{49}$

What was considered sayable or unsayable by witnesses in the courtroom (regardless of whether or not this was then reported in full by newspapers), perhaps especially with regard to sexual offences, followed distinctly specific lines of gender, age and class. ${ }^{50}$ Combined with the suspicion that false allegations of rape were endemic and details of any

\footnotetext{
44 Stevenson, "These are cases which it is inadvisable to drag into the light of day"'

45 This seems to have been broadly true of American newspapers as well: for this reason, Estelle Freedman notes that 'In the late 1870s tramps often dominated the coverage of rape'. See Freedman, "“Crimes which Startle and Horrify"', 476.

46 Western Mail, 29 November 1878, 3.

47 Bates, Sexual Forensics; Jackson, Child Sexual Abuse.

48 Framlingham Weekly News, 13 August 1870, 4.

49 Cook, 'Emotions, Bodies, Sexuality, and Sex Education', 475-95.

50 Krueger, 'Naming Privates in Public', 121-40.
} 
such allegation had to be forensically examined and cross-examined to determine its truthfulness, this inevitably left victims in an invidious position when asked to describe their experiences of abuse in detail during a hearing. ${ }^{51}$ Almost inevitably, children who repeated on oath any sexual comments made by their attacker would have these statements glossed over in print by journalists as 'a filthy expression (too filthy for publication)... [and] other details, of a very disgusting nature'. ${ }^{52}$ Those girls and boys who managed to successfully navigate this tightrope between providing sufficient information for their account to be believed and being perceived as 'knowing too much', or as having changed their story in parts, could not assume that this would lead to their attacker being convicted. Margaret Hopkins, aged 10 , was reduced to tears while giving evidence before the magistrates at Tredegar Police Court in May 1887 regarding her alleged rape by James Bradley, a travelling draper, and her account of the attack was reported by the South Wales Daily News as both unvarying when she was questioned and 'minutely described... the details of which were peculiarly revolting'. ${ }^{53}$ A doctor who had examined Hopkins also gave evidence supporting her claim she had been assaulted. ${ }^{54}$ Yet by the time it came to trial at the Monmouth Assizes two months later, the charge against Bradley had nonetheless been reduced to that of indecent assault, and he was acquitted by the jury..$^{55}$

Those children who could not fit neatly into this expected script of 'true victimhood' and who had not behaved in the 'expected' ways might well be accused of partial (or indeed full) responsibility for their attack, especially if they were over the age of 12 years. Even girls below the age of 11, however, could face searching questions about their moral character and might be asked whether they had ever behaved 'improperly' with boys from their neighbourhood. ${ }^{56}$ When Lambeth Police Court heard in January 1891 that Ernest Rohmer, a dealer in precious stones, was accused of indecently assaulting a 13-year-old girl who had run away from home during a cab journey between Peckham and Elephant and Castle, the magistrate heard the evidence and then concluded 'that he was satisfied no jury would convict, and the prisoner

${ }^{51}$ Jackson, 'The Child's Word in Court', 229-30; Stevenson, "Children of a Very Tender Age Have Vicious Propensities"'

52 Luton Times and Advertiser, 28 August 1875, 5.

53 South Wales Daily News, 18 May 1887, 3.

54 South Wales Echo, 18 May 1887, 2.

55 Weekly Mail, 23 July 1887, 5.

56 Jackson, Child Sexual Abuse, 96-9. 
would therefore be discharged'. ${ }^{57}$ Likewise, despite the fact (or perhaps because of it) that a 15 -year-old domestic servant was pregnant by the time her former employer's 20-year-old son was tried for her rape at the Leeds Assize in December 1902, the mere fact that he 'categorically denied the truth of the statements made by the girl' was apparently sufficient for the jury to acquit him..$^{58}$ In this latter case, the longstanding myth, still in vogue at the turn of the twentieth century, that immoral working-class women would attempt to pass off any conveniently available affluent man as the father of their illegitimate baby in order to gain a greater level of financial support, rather than giving the true identity, may well have also played a part in the man's acquittal. ${ }^{59}$

\section{Representing Perpetrators of Child Sexual Abuse}

Questions about what constituted normative and deviant masculinity lay at the heart of all trials of child sexual abuse in nineteenth-century England and Wales ${ }^{60}$ Since - despite its nineteenth-century roots - it was not until the late twentieth century that fears about paedophilia became widespread among either the medical profession or general public, the press and the criminal justice system had to seek alternative explanations for why such offences occurred. ${ }^{61}$ When 62 -year-old Thomas Welch was convicted of the rape of his 13-year-old stepdaughter at the Winchester Assizes in 1830 and sentenced to transportation for life, The Times did not hesitate to simply label him a 'monster' ${ }^{62}$ Yet the same article revealed that the jury in the case had taken a significantly more ambivalent view of Welch's guilt than the term 'monster' might otherwise suggest. Despite finding him guilty, they had queried whether, since 13 was at this time above the age of consent, his stepdaughter '... might have consented to the last offence' on the indictment, although they acknowledged her abuse had begun before she reached this age. ${ }^{63}$ It was presumably this fact, along with the testimony of Welch's other daughters that they had also been abused, that had secured his conviction. A defendant might also claim, as did one man at the Dunstable Sessions in August 1875, that the allegations of indecent assault were entirely fabricated by the child's

57 Reynold's Newspaper, 11 January 1891, 7.

58 Sheffield Daily Telegraph, 11 December 1902, 8.

59 Cretney, Family Law, 530.

${ }^{60}$ Jackson, Child Sexual Abuse, 107-31; Bates, Sexual Forensics, 158-89.

${ }_{61}$ Angelides, 'The Emergence of the Paedophile', 272-95.

62 The Times, 26 July 1830, 2.

${ }^{63}$ Ibid. 
parents out of spite. In this case, he argued, they resulted from his refusal to move goods for them while he was their lodger, since which there had been 'unpleasantness' between him and the family. ${ }^{64}$ Magistrates, judges, and jurors were regularly expected to evaluate whether the testimony of the victim or that of the accused was more believable in cases of child sexual abuse, and the extent to which a defendant was perceived as conforming to the standards expected of 'respectable' masculinity for a man of his class had a direct impact on this process and on how he was reported by the press. Although respectability and a good reputation within their community did not crudely translate into blanket immunity from conviction for either working-class or middle-class men accused of sexual offences, magistrates and jurors were more likely to give the benefit of the doubt to those with these attributes. Conversely, men who did not fit into this mould, like John Shepherd, whose response to being pursued by the father of the 5-year-old boy he had just assaulted in August 1881 was to repeatedly punch the other man in the face, then attack the police officers who tried to arrest him, were much more likely to be dealt with severely. ${ }^{65}$

Some newspaper articles did indeed focus in on the idea of a defendant as being especially monstrous, but this was unusual, and seems to have been at its most pronounced in the most egregious and undisputed cases of violence, such as homicides that were believed to have been sexually motivated. During the Islington coroner's inquest into the death of 7-year-old Elizabeth Ann Hunter in 1863, the Daily Telegraph reported that the coroner explicitly stated that he believed she had been murdered the previous year during the commission of a sexual assault, even if the child's body was too decomposed by the time it had been discovered to provide any physical evidence of this. ${ }^{66}$ The coroner also made clear to the jury that William Henry Clarke, the 17-year-old painter that the authorities suspected of killing Hunter, was already on remand awaiting trial for the indecent assault of three other girls aged below 10 years. ${ }^{67}$ In this instance, the coroner was also one of the medical men at the forefront of the campaign that argued only qualified physicians had sufficient knowledge to accurately determine causes of death when holding an inquest, which may also have accounted for his willingness to make this point so directly during

64 Luton Times and Advertiser, 28 August 1875, 5.

65 Nottingham Evening Post, 10 August 1881, 3.

66 Daily Telegraph, 8 August 1863, 3.

67 Ibid. 
the proceedings. ${ }^{68}$ In fact, it rapidly became clear that there was no way to provide sufficient evidence to proceed with a murder charge against Clarke, and the case had to be dropped. Nonetheless, Clarke was convicted at the Central Criminal Court on 17 August 1863 on charges of indecent assault against the three girls and sentenced to the maximum possible penalty of two years' imprisonment with hard labour. Following up on their earlier report, the Telegraph broke from convention to provide an unusually full (if still quite short) report on the trial, reflecting briefly but disapprovingly on the 'coolness' of Clarke when he was sentenced, and his implicit lack of any remorse. ${ }^{69}$

In one possibly unique instance, however, the reportage of sexual assault on a teenage boy by a middle-aged man defied all the usual patterns relating to these offences; therefore, it is worth discussing at length. ${ }^{70}$ In December 1843, Patrick Leigh Strachan, a 40-year-old 'gentleman' and former assistant secretary to the Governor of Sierra Leone, went on trial in the court of Queens' Bench for having indecently assaulted a 16-year-old public schoolboy, John George Scott. ${ }^{71}$ This case was highly unusual in a number of respects, not least of which that Queen's Bench normally dealt exclusively with civil law cases, rather than criminal offences such as this that would customarily have been heard at the Old Bailey. ${ }^{72}$ So, too, was the phenomenal level of detail (albeit in relative terms) about the case that was provided by the press reports when compared with other nineteenth-century newspaper articles about sexual violence. This detail was, in fact, the direct result of the shift in venue to Queen's Bench, where it was essential for a very full report to be produced as the entire point of these proceedings was to provide clarification in matters where there was a query over a point of law. ${ }^{73}$ It is also rare in dealing explicitly with both a perpetrator

68 Coroners in England and Wales were not required to hold any formal qualification until 1926, although the majority were trained as solicitors before this date. Those medics involved in this campaign were particularly keen to generate press reportage of the inquests they presided over. See Hurren, 'Remaking the Medico-Legal Scene', 207-52.

69 See the Daily Telegraph, 18 August 1863, p. 2, and the contrasting lack of any detail at all in the report from Old Bailey Proceedings Online (oldbaileyonline.org version 7.2, 31 March 2016), August 1863, trial of William Henry Clark (17) (t18630817-1002).

70 This was by far the most detailed such case report I have found at time of writing for 1830-1914.

71 The Times, 6 December 1843, 6.

72 Charles Upchurch has noted the Strachan trial was one of very few cases reported relating to sexual abuse of boys at public school. See Upchurch, Before Wilde, 56-7.

73 For this reason, the famous 1871 Boulton and Park sodomy trial ended up with a similarly unusual full and detailed report in The Times and other papers when it was heard by Queen's Bench: see Rowbotham, 'A Deception on the Public', 123-45. 
and their victim who were from the same upper-middle-class circles. Certainly, some newspapers followed the standard practice in sex crime cases of either ignoring the Strachan trial altogether or providing negligible information about it for their audiences. The Leicestershire Mercury, one of a few regional papers to even mention the case, merely included a single sentence in February 1844 informing readers of the outcome. ${ }^{74}$ Yet the two articles that ran in the law reports section of The Times, the middle-class 'newspaper of record', comprised over 7,200 words in total. ${ }^{75}$ Even for The Times, which took a special interest and pride in providing detailed reports of both civil and criminal legal matters during the nineteenth century, ${ }^{76}$ this was an exceptional and extensive pair of articles about a single case, especially since the trial took place in just one day, with a delay of a couple of months before sentence was pronounced.

Reading the trial reports and the evidence given by witnesses, a contemporary reader is immediately struck by the parallels between this scenario from the 1840 s and twenty-first-century 'grooming' cases of child sexual abuse. ${ }^{77}$ Having originally met John Scott on a ship sailing from Greenock to Liverpool, Strachan made repeated efforts to build up an acquaintance with the whole family. He invited Scott out for one or two individual trips around London over a period of several weeks, but was also careful to invite Scott's 'father, mother, aunt, and myself, to several of the clubs - the Parthenon, Reform, \& c.' ${ }^{78}$ By conspicuously demonstrating that he was part of these groups, Strachan was relying on this apparent fit with the criterion of respectable middle-class masculinity in order to lull any suspicions and get closer to his intended victim. ${ }^{79}$ About three months later, Strachan arrived unannounced at Scott's lodgings and, on having asked to see his room, attempted to assault him once they were alone. Scott managed to shove him away, and Strachan reluctantly agreed to leave but unsuccessfully attempted to persuade the boy to tell his guardians at the lodgings that he should be allowed to stay the night having missed his train. Shortly afterwards, Scott reported what had happened, and Strachan was then arrested.

One particularly interesting angle of the Times reports was the way in which the subject of the defendant's imperial service in West Africa was

\footnotetext{
Leicestershire Mercury, 3 February 1844, 3.

The Times, 6 December 1843, 6; The Times, 1 February 1844, 6.

6 Rowbotham, Stevenson and Pegg, Crime News in Modern Britain.

7 See for example Mcalinden, "'Setting 'Em Up", 339-62.

The Times, 6 December 1843, 6.

9 Tosh, A Man's Place; Milne-Smith, London Clubland.
} 
referred to (or ignored) in court. Strachan had occupied an influential role during his time in Sierra Leone and had evidently maintained these connections with former Colonial Office colleagues on his return to Britain..$^{80}$ Indeed, one witness called to speak in his defence, the former Member of Parliament for Selkirk, noted that this experience, coupled with a reputation 'of the best description' had meant that when back in the United Kingdom, Strachan had rapidly secured an unspecified government post through these influential networks. ${ }^{81}$ A colour aquatint of the colony capital, captioned $A$ View of Freetown, Sierra Leone and produced in London by the famous painter Edward Duncan and the printer William John Huggins in 1837, was 'Dedicated by permission to the Right Hon.ble Lord Glenelg Her Majesty's Principal Secretary of State for Colonies by PATRICK LEIGH STRACHAN ESQ.R, Private Secretary to His Excellency Rich.d Doherty, Governor in Chief of the Western Coast of Africa, \&c. ${ }^{92}$

Lieutenant-Colonel Campbell, a former governor of Sierra Leone who testified that he had worked closely with Strachan during their time in the colony, remained on friendly terms since and insisted he could not believe that such a crime as this could be committed by one whose 'character was particularly high as a man of honour and delicacy'. ${ }^{83}$ This shared period of service overseas to the empire was for Campbell, and would have been for others, in itself de facto evidence of cast-iron masculine respectability. A number of upper- and middle-class male witnesses, including both the Physician in Ordinary to the Queen and the Sheriff of Orkney and Zutland, also gave emphatic statements assuring the bench that in their experience Strachan was unanimously known as a man of excellent moral character and, moreover, one who was constantly welcomed in 'the best circles' of society. ${ }^{84}$ As such, they considered the charges against him to be ludicrous. Following Strachan's conviction, however, the counsel for the defence attempted to argue that, despite there being no mention in previous testimony of anything beyond an impeccable character, Strachan's eight years' work in Sierra Leone had meant that he returned 'with a shattered constitution and with a mind enfeebled by the disease with which he had been visited' ${ }^{85}$ Although

\footnotetext{
80 A key study of the workings of the Colonial Office in this period is Laidlaw, Colonial Connections

81 The Times, 6 December 1843, 6.

82 On the broader context of Sierra Leone as a British colony in the early nineteenth century, see Everill, Abolition and Empire.

83 The Times, 6 December 1843, 6.

84 On the rituals of 'Society' in this period see Davidoff, The Best Circles.

85 The Times, 1 February 1844, 6.
} 
the defence could not claim that Strachan had been left so damaged he was no longer responsible for his actions, the lawyer urged the court to take into account his poor health, previous excellent character and dedicated service overseas for the good of the nation. The plea for mitigation, however, was largely ignored. The bench completely disregarded any of the claims to imperial heroism made by witnesses or counsel for the defence. ${ }^{86}$ Instead, bluntly warning Strachan that if he had managed to complete his purpose he could have faced execution for sodomy, $\mathrm{Mr}$ Justice Patteson sentenced him to eighteen months' imprisonment with hard labour at Clerkenwell Prison. ${ }^{87}$ It seems to have been especially disquieting to the court that, 'under circumstances of considerable deliberation', Strachan had been able to use the benefits of his class and social connections to try and molest public school boys of a similar privileged background as both himself and the judges hearing the case. As a result, the judges seem to have been keen to make an example of Strachan. ${ }^{88}$ As such, Strachan was unable to benefit from his previous positions of wealth and influence and given a relatively heavy sentence.

\section{Conclusion}

Newspaper articles reporting on cases of alleged sexual abuse of boys and girls of all ages in England and Wales between 1830 and 1914 are often frustratingly fragmentary. Where they do exist in more copy than a few lines, however, these articles can be surprisingly rich in what they reveal about attitudes to gender, sexuality, class, and age. As with press reports of other sorts of criminality during this period, the more closely a defendant could be presented as conforming to appropriate class and gender norms, the more likely it became they would be viewed with sympathy by readers. Victims were also reported on, and judged, in similar terms. In cases of alleged child sexual abuse, where by definition the girl or boy who made the complaint was admitting to a sexual (even if non-consenting) experience, this had a particularly deleterious impact on the chances of securing a conviction. Adolescent girls in particular were disturbingly likely to run the risk of

86 Conversely, however, the judges also did not take the opportunity to suggest that it was exposure to supposedly 'inferior' cultures and alternative sexual mores in West Africa that may have lead to his desire for same-sex contact, which was one way this could have been interpreted by the authorities: see Phillips, Sex, Politics and Empire, 163-89.

87 The Times, 1 February 1844, 6. This warning by the judge was presumably designed to frighten Strachan. Although it remained a capital offence until 1861, the last execution carried out for sodomy in England had been in 1835.

88 Ibid. 
being labelled as sexually precocious, rather than seen as vulnerable. ${ }^{89}$ These recurring issues of euphemism and silence, and the shifting sands of blame in the reporting of child sexual abuse (coupled with a relatively low rate of successful prosecution) have not, of course, been confined to nineteenth-century England and Wales. In addition to a continuing poor rate of convictions in the assize courts, the British press repeatedly resorted to euphemism and silences in reporting (or failing to report) cases of sexual violence against children during the course of the twentieth century. ${ }^{90}$ This remained the case despite the substantial changes wrought in the press by interwar stylistic, cultural, and technological innovations, including a dramatic increase in the reproduction of images and greater willingness to directly tackle controversial stories with a sexual or criminal element. ${ }^{91}$ Indeed, Shurlee Swain has recently suggested that the longstanding emphasis in newspaper articles and in the courtroom on the supposed potential complicity of the victim in cases of child sexual abuse meant that it was not until the 1970 s that survivors of such attacks were able to fully articulate their experiences. $^{92}$

89 Bates, 'The Child as Risk'.

90 On the history of child sexual abuse in England and Wales after 1900 see Smart, 'A History of Ambivalence and Conflict', 391-409; Smart, 'Reconsidering the Recent History of Child Sexual Abuse', 55-71; Brown and Barrett, Knowledge of Evil; Bingham, Delap, Jackson and Settle, 'Historical Child Sexual Abuse'; Grey, 'Introduction', 1-5; Delap, “'Disgusting Details Which Are Best Forgotten”'.

${ }^{91}$ Bingham, Family Newspapers: Sex, Private Life, and the British Popular Press.

${ }_{92}$ Swain, 'Giving Voice', 289-304. 